\title{
Morpho-Physiological Variability in Alternaria carthami Chowdhury Causing Safflower Leaf Spot
}

\author{
M.R. Madhu ${ }^{1 *}$, M.P. Basavarajappa ${ }^{2}$, I.D. Anand ${ }^{1}$ and Chidanand Lokapur ${ }^{1}$ \\ ${ }^{1}$ Department of Plant Pathology, University of Agricultural sciences, \\ Dharwad-580 005, Karnataka, India \\ ${ }^{2}$ University of Horticultural Sciences, Bagalkot-587 104, Karnataka, India \\ *Corresponding author
}

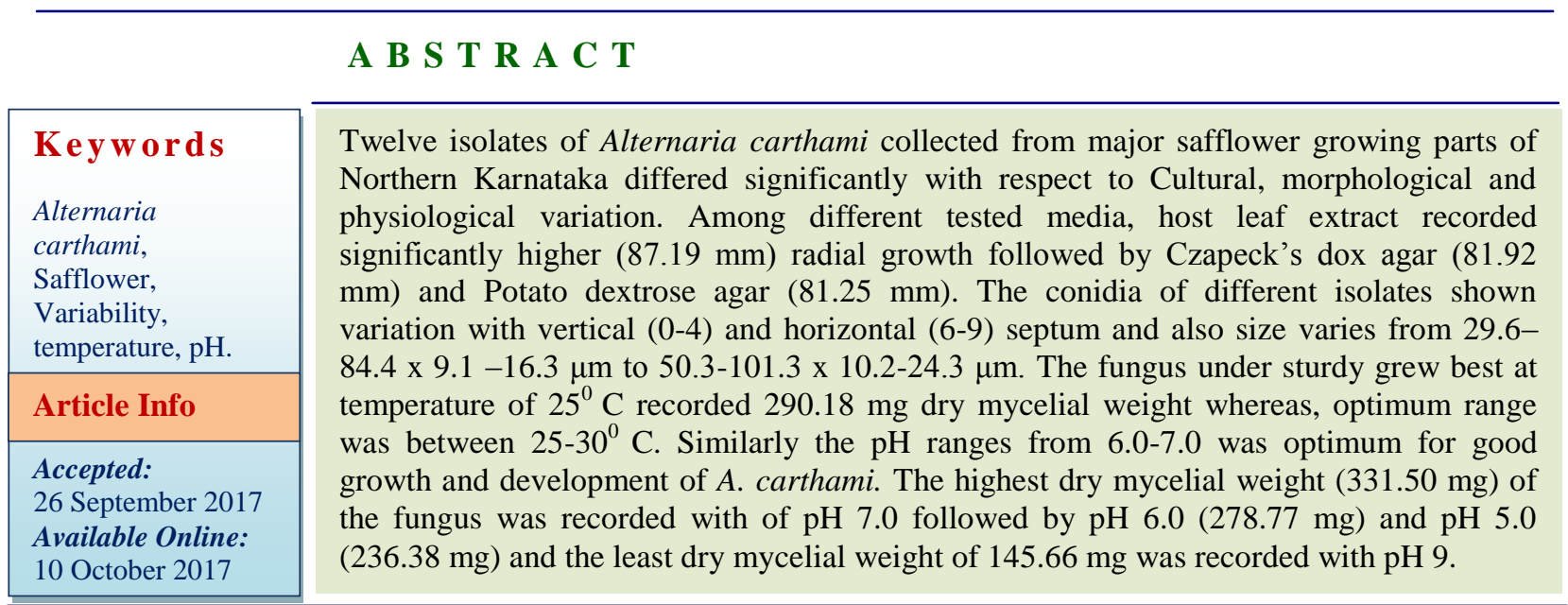

\section{Introduction}

In India Safflower (Carthamus tinctorius L.) is known for its orange-red dye extracted from its brilliant florets besides high-quality edible oil rich in polyunsaturated fatty acids. Safflower oil is nutritionally similar to olive oil, as it contains high levels (78\%) of linoleic or oleic acid. Leaves are rich in carotene, riboflavin and vitamin $\mathrm{C}$ owing to these seedlings and prunings are used as green leafy vegetable. The safflower production in India is about 1.89 lakh tonnes with bulk of the production concentrated in the states of Maharashtra and Karnataka. The leaf spot disease caused by Alternaria carthami Chowdhury is a major destructive disease of safflower in India. The disease occurred in epidemic form during 1997 in all safflower growing areas of Maharashtra, Andhra Pradesh and Karnataka states of India due to high humidity coupled with continuous rains during pre-flowering period. The disease caused severe losses in seed yield in the trials in most of the locations in Maharashtra and Karnataka. The disease has been reported to cause seed yield losses to the tune of 10 to 25 per cent (Indi et al., 1988). Under severe conditions, it has been reported to cause 50 per cent loss in seed yield (Indi et al., 1986 and Singh and Prasad, 2005). The disease assumes endemic proportion in most of the safflower growing areas of Karnataka, Maharashtra and Andhra Pradesh. The present 
experiment on variability studies on cultural, morphological and physiological features of the pathogen are of immense utility in understanding the nature of the pathogen to arrive at pragmatic remedies to manage the disease.

\section{Materials and Methods}

The safflower leaves showing the typical leaf spot symptoms were collected from different northern parts of Karnataka viz., Dharwad (Ac1), Hubli (Ac2), Navalagund (Ac3), Annigeri (Ac4), Kundagol (Ac5), Naragund (Ac6), Rona (Ac7), Hunagund (Ac8), Badami (Ac9), Bijapura (Ac10), Bagevadi (Ac11) and Muddebihal (Ac12) and pathogen A. carthami was isolated by standard tissue isolation technique in the laboratory. Further, the pure culture of the fungus was obtained by single spore isolation method and maintained on Potato dextrose agar (PDA) slants for further use. Pathogenicity was proved by spraying spore and mycelial suspension on 30 days old manjira susceptible variety. The study was conducted in the Department of Plant Pathology, College of Agriculture, Dharwad, Karnataka, India.

\section{Cultural variability of $A$. carthami on different solid medium}

The cultural characters of 12 isolates of $A$. carthami were grown on various solid media viz., Potato dextrose agar (PDA), host leaf extract (HLE), Czapeck's dox agar (CZ) and Richards' agar (RA). Five $\mathrm{mm}$ discs of actively growing $A$. carthami culture were cut using a cork borer and a single disc was placed in a Petri plate containing above media in aseptic condition. Each set of experiment was replicated thrice and the plates were incubated at $27 \pm 1^{0} \mathrm{C}$ for 12 days. The radial growth of the pathogen from the centre to the periphery of Petri plate was measured for all the media and data was analyzed statistically.

\section{Morphological variability of $A$. carthami on potato dextrose agar}

The isolates of A. carthami were collected from Dharwad, Vijayapur, Gadag and Bagalkot districts (Acl to Ac12) were used for the study. These isolates were grown on PDA and studied for morphological characters such as length and width of conidia, number of horizontal and vertical septa and beak length using Differential interference contrast microscope under 40X magnification.

\section{Physiological variability of $A$. carthami}

\section{Effect of different temperature levels on the growth of $A$. carthami}

All the twelve isolates of $A$. carthami were grown at $15,20,25,30,35$ and $40^{\circ} \mathrm{C}$ on Potato dextrose broth (PDB). Thirty milliliters of PDB was prepared in $100 \mathrm{ml}$ conical flask and then sterilized. Five mm diameter discs of ten days old mycelia of all the isolates of $A$. carthami were inoculated and incubated at different temperatures for 12 days, three replications were maintained. Cultures were filtered through Whatman No. 1 filter paper and dry mycelia weights were recorded.

\section{Effect of different pH levels on the growth of $A$. carthami}

All twelve isolates of $A$. carthami were grown on the PDB with $\mathrm{pH}$ levels of 4.0, 5.0, 6.0, $7.0,8.0$ and 9.0 by adjusting with $1 \mathrm{~N}$ alkali $(\mathrm{NaOH})$ or acid $(\mathrm{HCl})$. Five $\mathrm{mm}$ mycelial discs of all the isolates were inoculated separately into $100 \mathrm{ml}$ conical flasks containing $30 \mathrm{ml}$ medium at different $\mathrm{pH}$ levels and three replications were maintained. After incubation at $27 \pm 1^{0} \mathrm{C}$ for 12 days, the mycelial growth was harvested, washed, dried in hot air oven and the dry weights were recorded as described earlier. 


\section{Results and Discussion}

Totally twelve isolates were collected from different northern parts of Karnataka. The isolation of pathogen was done using standard tissue isolation and the pure culture of the fungus was obtained by single spore isolation after eight days of inoculation. Based on cultural and spore morphology the fungus identified as Alternaria carthami and the isolates were coded as Acl to Acl2 with respect to their location names as Dharwad (Ac1), Hubli (Ac2), Navalagund (Ac3), Annigeri (Ac4), Kundagol (Ac5), Naragund (Ac6), Rona (Ac7), Hunagund (Ac8), Badami (Ac9), Bijapura (Ac10), Bagevadi (Acl1) and Muddebihal (Ac12). Further isolates were used for variability studies.

\section{Cultural variability of $A$. carthami on} different solid medium

The diversity in cultural characters of the isolates of A. carthami were subjected for their growth habit on different solid media. Among the four different media, host leaf extract agar has recorded significantly higher mean radial growth of $87.19 \mathrm{~mm}$ which was superior over other three media. Further, CZ $(81.92 \mathrm{~mm})$ and PDA $(81.25 \mathrm{~mm})$ both remained on par with each other while the lowest growth of the fungus was observed on RA $(79.03 \mathrm{~mm})$ respectively. Among different isolates, Ac12 $(88.25 \mathrm{~mm})$ has recorded maximum mean radial growth, which was on par with $A c 5(86.92 \mathrm{~mm})$ followed by Ac10 $(84.50 \mathrm{~mm}), \operatorname{Ac} 8(84.42$ $\mathrm{mm})$ and Ac11 $(84.33 \mathrm{~mm})$ while the least mean radial growth was recorded by $A c 4$ $(76.75 \mathrm{~mm})$. With respect to isolates and media interaction, Ac5 on RA $(90.00 \mathrm{~mm})$ showed maximum radial growth which was on par with Ac12 on HLE $(89.67 \mathrm{~mm})$. Result presented that the colour of colony varied from light grey to dark grey in HLE, PDA, $\mathrm{CZ}$, media, whereas in RA it varied form creamy white to light pinkish. With respect to growth and margin, variations observed were from flat to rough raised and regular to smooth margin on all the four media. Further poor to good sporulation was recorded in HLE, whereas poor to moderate sporulation was observed on PDA and CZ while poor sporulation or no sporulation was seen in RA. Similar results were reported by Prasad et al., (2012) who revealed that the maximum radial mycelia growth of $A$. carthami was more on skim milk agar medium followed by safflower leaf extract medium and Potato Carrot Agar medium and low growth was on Potato dextrose agar media. Sporulation was more on Potato carrot agar followed by safflower leaf extract agar media. The results are found in accordance with the reports of Somappa et al., (2013) who observed the maximum radial growth on Czapeck's dox agar medium followed by PDA (Table 1).

\section{Morphological variability of $A$. carthami on potato dextrose agar}

The morphology of all the isolates varied with respect to the conidia size, beak length and number of vertical and horizontal septa. The conidia of different isolates varied in septation (0-4 vertical and 6-9 horizontal). The isolates Acl, Ac2, Ac4, Ac5, Ac6, Ac8, Ac10 and Ac11 showed maximum horizontal septa up to 7-9 on the contrary minimum horizontal septa (6-7) was observed in the remaining isolates. The isolates Ac2 showed maximum of 0-4 vertical septa whereas minimum vertical septa (0-2) were observed in remaining isolates. Among the isolates, Ac10 and Ac7 showed maximum size of 50.3- 101.3 x 10.2-24.3 $\mu \mathrm{m}$ and 52.5-85.2 $\mathrm{x}$ 8.6-27.3 $\mu \mathrm{m}$, respectively. The least size of the conidia was observed in isolate Ac2 (29.6$84.4 \times 9.1-16.3)$. The presence of conidial beak was seen in all the isolates, but there was variation in terms of length of beak. The isolate Ac12 showed maximum beak length of 51.8-96.4 $\mu \mathrm{m}$ while the least beak length 
was observed in isolate Ac9 (26.4-30.2 $\mu \mathrm{m})$. Similar results were reported by Prasad et al., (2012) where the variations amongst isolates of $A$. carthami conidia were owing to the production of conidia in either solitary or short chains besides the size of conidia varied from $28 \times 80 \mu \mathrm{m}$ to $40 \times 104 \mu \mathrm{m}$. The present morphological description corroborated the earlier findings on A. carthami by Chowdhury (1944) where the observation was light brown conidia of variable shape, occurring in chains of at least two and consisting of 3-11 cells, with up to six longitudinal septa, measuring about 36-99 x 12-28 $\mu \mathrm{m}$ and beak length ranges from 15-84 x 3-5 $\mu \mathrm{m}$. Moreover, Mahabaleswarappa (1981) opined that the shape of the conidia varied from roughly spherical to elongate, light brown, slightly constricted at the septa with long beak (Table 2).

Table.1 Morphological variation among different isolates of Alternaria carthami

\begin{tabular}{|l|c|c|c|c|}
\hline \multirow{2}{*}{$\begin{array}{l}\text { Name of } \\
\text { isolate }\end{array}$} & \multicolumn{2}{|c|}{ Septation } & $\begin{array}{c}\text { Conidia size } \\
\text { Length }(\boldsymbol{\mu m}) \times \text { Width }(\boldsymbol{\mu m})\end{array}$ & $\begin{array}{c}\text { Beak } \\
\text { Length }(\boldsymbol{\mu m})\end{array}$ \\
\cline { 2 - 3 } $\boldsymbol{A c 1}$ & Vertical & Horizontal & $34.1-101.1 \times 9.2-27.2$ & $27.5-61.3$ \\
\hline $\boldsymbol{A c 2}$ & $0-3$ & $7-9$ & $29.6-84.4 \times 9.1-16.3$ & $32.8-44.6$ \\
\hline $\boldsymbol{A c 3}$ & $0-4$ & $7-9$ & $42.0-93.6 \times 18.7-27.6$ & $28.4-59.9$ \\
\hline $\boldsymbol{A c 4}$ & $0-2$ & $6-7$ & $46.9-97.9 \times 10.5-25.0$ & $38.0-80.6$ \\
\hline $\boldsymbol{A c 5}$ & $0-2$ & $7-9$ & $36.2-84.4 \times 8.5-13.1$ & $26.7-43.9$ \\
\hline $\boldsymbol{A c 6}$ & $0-2$ & $7-9$ & $42.0-93.5 \times 18.6-27.6$ & $36.7-59.2$ \\
\hline $\boldsymbol{A c 7}$ & $0-2$ & $7-9$ & $52.5-85.2 \times 8.6-27.3$ & $34.7-61.2$ \\
\hline $\boldsymbol{A c \boldsymbol { B }}$ & $0-2$ & $6-7$ & $37.3-96.2 \times 10.3-28.3$ & $42.6-71.2$ \\
\hline $\boldsymbol{A c 9}$ & $0-3$ & $7-9$ & $30.3-96.2 \times 8.6-20.1$ & $26.3-30.3$ \\
\hline $\boldsymbol{A c 1 0}$ & $0-2$ & $6-7$ & $50.3-101.3 \times 10.2-24.3$ & $39.7-56.2$ \\
\hline $\boldsymbol{A c 1 1}$ & $0-2$ & $7-9$ & $39.0-100.4 \times 12.3-26.9$ & $44.7-84.23$ \\
\hline $\boldsymbol{A c 1 2}$ & $0-2$ & $7-9$ & $37.3-96.6 \times 10.6-17.0$ & $51.8-96.4$ \\
\hline
\end{tabular}

Table.2 Growth of $A$. carthami isolates on different solid media

\begin{tabular}{|c|c|c|c|c|c|}
\hline \multirow{2}{*}{ Name of isolate } & \multicolumn{4}{|c|}{ Redial growth (mm) } & \multirow{2}{*}{$\begin{array}{l}\text { Mean redial } \\
\text { growth }(\mathrm{mm})\end{array}$} \\
\hline & HLE & PDA & $\mathbf{C Z}$ & RA & \\
\hline Ac1 & 88.00 & 75.00 & 82.67 & 68.00 & 78.42 \\
\hline Ac2 & 86.67 & 81.00 & 81.33 & 70.33 & 79.83 \\
\hline Ac3 & 81.00 & 88.00 & 70.00 & 77.33 & 79.08 \\
\hline Ac4 & 83.67 & 72.33 & 79.00 & 72.00 & 76.75 \\
\hline Ac5 & 88.67 & 84.67 & 84.33 & 90.00 & 86.92 \\
\hline Ac6 & 89.33 & 83.33 & 71.33 & 78.67 & 80.67 \\
\hline Ac7 & 88.33 & 76.00 & 85.67 & 74.67 & 81.17 \\
\hline Ac8 & 88.33 & 81.00 & 87.00 & 81.33 & 84.42 \\
\hline Ac9 & 86.33 & 81.33 & 81.00 & 86.67 & 83.83 \\
\hline Ac10 & 89.00 & 79.00 & 84.67 & 85.33 & 84.50 \\
\hline Ac11 & 87.33 & 85.67 & 89.33 & 75.00 & 84.33 \\
\hline Ac12 & 89.67 & 87.67 & 86.67 & 89.00 & 88.25 \\
\hline \multirow[t]{2}{*}{ Mean } & 87.19 & 81.25 & 81.92 & 79.03 & 82.35 \\
\hline & \multicolumn{2}{|c|}{ Isolate $(\mathrm{I})$} & \multicolumn{2}{|c|}{ Media $(\mathbf{M})$} & I $\mathbf{x M}$ \\
\hline S.Em. \pm & \multicolumn{2}{|c|}{0.54} & \multicolumn{2}{|c|}{0.31} & 1.09 \\
\hline CD at $1 \%$ & \multicolumn{2}{|c|}{2.18} & \multicolumn{2}{|c|}{1.26} & 4.36 \\
\hline
\end{tabular}

Note: HLE- Host leaf extract, PDA-Potato dextrose agar, CZ- Czapeck's Dox agar, RA- Richards' agar 
Table.3 Effect of different temperature levels on the growth of $A$. carthami isolates

\begin{tabular}{|c|c|c|c|c|c|c|c|}
\hline \multirow{2}{*}{ Name of Isolate } & \multicolumn{6}{|c|}{ Temperature levels ${ }^{0} \mathrm{C}$ (Dry mycelial weight in $\mathrm{mg}$ ) } & \multirow{2}{*}{ Mean } \\
\hline & 15 & 20 & 25 & 30 & 35 & 40 & \\
\hline Ac1 & 66.00 & 212.50 & 343.00 & 249.75 & 188.75 & 68.00 & 188.00 \\
\hline$A c 2$ & 58.75 & 156.00 & 291.50 & 231.50 & 122.50 & 71.25 & 155.16 \\
\hline Ac3 & 62.75 & 166.00 & 300.25 & 272.75 & 126.25 & 84.00 & 168.66 \\
\hline Ac4 & 66.25 & 150.50 & 283.25 & 240.25 & 87.50 & 79.50 & 151.20 \\
\hline Ac5 & 72.00 & 185.75 & 290.25 & 263.00 & 144.50 & 79.50 & 172.50 \\
\hline Ac6 & 69.75 & 208.25 & 284.50 & 249.00 & 138.00 & 66.75 & 169.37 \\
\hline Ac7 & 59.00 & 195.50 & 331.00 & 244.25 & 134.75 & 65.75 & $\mathbf{1 7 1 . 8 7}$ \\
\hline$A c 8$ & 66.25 & 174.75 & 241.00 & 284.75 & 130.50 & 85.75 & 163.83 \\
\hline$A c 9$ & 74.25 & 178.00 & 228.75 & 254.25 & 128.75 & 68.75 & 155.45 \\
\hline Ac10 & 67.25 & 208.75 & 231.25 & 309.25 & 172.50 & 69.75 & 176.50 \\
\hline Ac11 & 67.00 & 219.25 & 256.50 & 221.25 & 112.25 & 75.50 & 158.62 \\
\hline Ac12 & 60.50 & 143.50 & 322.75 & 235.70 & 92.75 & 72.25 & 154.54 \\
\hline \multirow[t]{2}{*}{ Mean } & 65.81 & 183.22 & 290.18 & 248.20 & 131.54 & 73.89 & 165.47 \\
\hline & \multicolumn{2}{|c|}{ Isolate (I) } & \multicolumn{2}{|c|}{ Temperature (T) } & \multicolumn{3}{|c|}{$\mathbf{I} \times \mathbf{T}$} \\
\hline S.Em. \pm & \multicolumn{2}{|c|}{1.00} & \multicolumn{2}{|c|}{0.70} & \multicolumn{3}{|c|}{2.45} \\
\hline $\mathrm{CD}$ at $1 \%$ & \multicolumn{2}{|c|}{4.01} & \multicolumn{2}{|c|}{2.83} & \multicolumn{3}{|c|}{9.83} \\
\hline
\end{tabular}

Table.4 Effect of different $\mathrm{pH}$ levels on the growth of $A$. carthami isolates

\begin{tabular}{|c|c|c|c|c|c|c|c|}
\hline \multirow{2}{*}{ Name of Isolate } & \multicolumn{6}{|c|}{ Different pH levels (Dry mycelial weight in mg) } & \multirow{2}{*}{ Mean } \\
\hline & 4 & 5 & 6 & 7 & 8 & 9 & \\
\hline Ac1 & 236.00 & 286.00 & 315.00 & 384.67 & 215.00 & 189.00 & 270.94 \\
\hline Ac2 & 130.67 & 233.67 & 289.33 & 385.00 & 235.00 & 131.33 & 234.17 \\
\hline Ac3 & 101.00 & 214.00 & 230.67 & 285.67 & 210.00 & 102.67 & 190.67 \\
\hline Ac4 & 88.00 & 239.33 & 284.67 & 365.67 & 216.00 & 131.00 & 220.78 \\
\hline Ac5 & 184.33 & 232.67 & 274.67 & 325.00 & 188.67 & 144.33 & 224.94 \\
\hline Ac6 & 146.00 & 267.33 & 288.00 & 395.33 & 247.67 & 190.00 & 255.72 \\
\hline Ac7 & 87.33 & 153.00 & 198.33 & 259.33 & 147.33 & 103.67 & 158.17 \\
\hline$A c 8$ & 187.67 & 235.67 & 276.33 & 261.33 & 178.67 & 95.33 & 205.83 \\
\hline$A c 9$ & 155.67 & 237.67 & 325.33 & 273.67 & 152.00 & 120.00 & 210.72 \\
\hline Ac10 & 247.67 & 289.33 & 315.00 & 425.33 & 255.00 & 203.67 & 289.33 \\
\hline Ac11 & 184.67 & 244.00 & 265.00 & 290.33 & 215.00 & 159.33 & 226.39 \\
\hline Ac12 & 179.67 & 204.00 & 283.00 & 326.67 & 220.67 & 171.67 & 230.94 \\
\hline \multirow[t]{2}{*}{ Mean } & 160.72 & 236.38 & 278.77 & 331.50 & 206.75 & 145.16 & 226.55 \\
\hline & \multicolumn{3}{|c|}{ Isolate (A) } & \multicolumn{3}{|c|}{ pH (B) } & A X B \\
\hline S.Em. \pm & \multicolumn{3}{|c|}{1.01} & \multicolumn{3}{|c|}{0.71} & 2.49 \\
\hline CD at $1 \%$ & \multicolumn{3}{|c|}{4.05} & \multicolumn{3}{|c|}{2.86} & 9.92 \\
\hline
\end{tabular}


Further, the conidia had transverse septa (up to 11) and longitudinal septa (up to 6), the total length ranged from 22.8-119.4 $\mu \mathrm{m}$ including of beak length with beak length being 8.8-52.5 $\mu \mathrm{m}$ and width of conidia 9.65$20.65 \mu \mathrm{m}$. Observations on morphological characteristics of $A$. carthami, dark grey colonies, conidiophores simple erect, septate, 40-80 $\mu \mathrm{m}$ length, conidia solitary, straight, size of conidia without beak 40-100 $\mu \mathrm{m}$ long, 10-15 $\mu \mathrm{m}$ thick, number of transverse septa 410 and longitudinal septa 4-7, beak with 2-4 septa and 30-65 $\mu \mathrm{m}$ length (Park and Lee, 2003) remained valid testimonials for the current results. The variations among the isolates were also observed by earlier workers (Mortensen and Bergman, 1983; Deokar and Raghuwanshi, 2002).

\section{Physiological variability of $A$. carthami}

\section{Effect of different temperature levels on growth of $A$. carthami isolates}

The growth of the isolates gradually increased from $15^{\circ} \mathrm{C}$ to $25^{\circ} \mathrm{C}$ and then showed reduction in dry mycelial weight from $30^{\circ} \mathrm{C}$ onwards. Among different incubated temperatures, the highest mean dry mycelial weight was recorded at $25^{\circ} \mathrm{C}(290.18 \mathrm{mg})$ followed by $30^{\circ} \mathrm{C}(248.20 \mathrm{mg})$ while the lowest was observed at $15^{\circ} \mathrm{C}(65.81 \mathrm{mg})$. Isolates $A c 8$, $A c 9$ and $A c 10$ showed good growth at $30^{\circ} \mathrm{C}$ on the contrary rest of all the isolates showed good growth at $25^{\circ} \mathrm{C}$. The significant interaction difference was also observed between isolates and temperature. The highest dry mycelial weight recorded in Acl (343.00 $\mathrm{mg}$ ) at $25^{\circ} \mathrm{C}$ which was significantly superior over other isolates and temperature combination and least dry mycelial weight was recorded at $15^{\circ} \mathrm{C}$ in isolate $A c 2(58.75$ $\mathrm{mg})$.

The experimental results on different temperatures revealed that, all the isolates grew well at $25^{\circ} \mathrm{C}$ and also at $30^{\circ} \mathrm{C}$. Therefore 25 to $30^{\circ} \mathrm{C}$ temperature was optimum for growth and development of the fungus. These results were in confirmation with the reports of Chowdhury (1944); Mahabaleswarappa (1981); Arumkumar (2006); Ramegowda and Naik (2008); Naik et al., (2010); they also revealed that $25-30^{\circ} \mathrm{C}$ was optimum for the growth of the fungus (Table 3).

\section{Effect of different $\mathrm{pH}$ levels on growth of A. carthami isolates}

The isolates, reactions and their interaction offered significant differences with respect to the dry mycelial weight of $A$. carthami at different $\mathrm{pH}$ level of the media. Growth of all the isolates gradually increased from acidic to neutral $\mathrm{pH}$ and then showed the drastic reduction at alkaline $\mathrm{pH}$.

Among different $\mathrm{pH}$ levels, mean dry mycelial weight remained higher at $\mathrm{pH} 7$ (331.5 mg), followed by $\mathrm{pH} 6(278.8 \mathrm{mg})$ and the least dry mycelia weight was recorded at $\mathrm{pH} 9$ (145.2 $\mathrm{mg})$. The interaction between isolates and $\mathrm{pH}$ also resulted in significant variations with respect to dry mycelial weight. The growth of AclO (425.3 mg) at $\mathrm{pH} 7$ which was significantly superior over growth of other isolates and $\mathrm{pH}$ levels, followed by Ac6 (395.3 mg), Ac2 (385.0 mg) Acl (384.7 $\mathrm{mg}$ ) which were on par with each other. The least dry mycelia weight was recorded at $\mathrm{pH} 4$ in Ac7 $(87.3 \mathrm{mg})$ which was on par with Ac4 $(88.0 \mathrm{mg}$ ) at same $\mathrm{pH}$ as well as with $A c 8$ (95.3 mg) at pH 9 (Table 4).

The present investigation revealed that the pathogen grows well in the $\mathrm{pH}$ range of 4-9, but optimum $\mathrm{pH}$ range for better growth and development of $A$. carthami was $\mathrm{pH} 6$ to 7 . The results were found similar with studies of Chowdhury (1944) who reported the maximum dry mycelial weight at $\mathrm{pH} 6$, with 
an optimum $\mathrm{pH}$ of 6-7 growth of $A$. carthami and also by Mahabaleswarappa (1981) who reported the maximum dry mycelial weight at $\mathrm{pH}$ 6. The earlier workers also observed significant growth was $\mathrm{pH}$ range of 6 to 7 (Arunkumar, 2006; Mesta, 2006).

\section{References}

Arunakumara, K. T., 2006, Studies on Alternaria solani (Ellis and Martin) Jones and Grout causing early blight of tomato. M. Sc. (Agri.) Thesis. Univ. Agric. Sci., Dharwad, Karnataka (India).

Chowdhury, S., 1944, An Alternaria disease of safflower. J. Indian Bot. Sci., 23: 5965.

Deokar, C. D., and Raghuwanshi, K. S., 2002, Morphological variation of Alternaria carthami isolates on different growth media. Sesame and Safflower Newsletter, 17: 115-116.

Indi, D.V., Lukade, G.M. and Patil, P.S. 1986. Influence of Alternaria leaf spot (Alternaria carthami Chowdhary) on growth and yield of safflower. Curr. Res. Rep. 2(1): 137-139.

Indi, D.V., Lukade, G.M., Patil, P.S. and Shambharkar, D.A. 1988. Estimation of yield losses due to Alternaria leaf spot in safflower (c.o. Alternaria carthami Chowdhary) under dryland conditions. Pesticides 22(1): 41-43.

Mahabaleswarappa, K. B., 1981, Studies on leaf spot of safflower caused by Alternaria carthami Chowdhury. M. Sc. (Agri.) Thesis. Univ. Agric. Sci., Bangalore (India).

Mesta, R. K., 2006, Epidemiology and management of Alternaria blight of sunflower caused by Alternaria helianthi (Hansf.) Tubaki and Nishihara. Ph. D. Thesis. Uni. Agric. Sci., Dharwad (India).

Mortensen, K., and Bergman, J. W., 1983, Cultural Variance of Alternaria carthami isolates and their virulence on safflower. Pl. Dis. Rep., 67: 1187-1190.

Naik, M. K., Prasad, Y., Bhat K. V. and Devikarani, G. S., 2010, Morphological, physiological, pathogenic and molecular variability among isolates of Alternaria solani from tomato. Indian Phytopath., 63(2): 168-173.

Park, K. S., and Lee, S. G., 2003, Leaf Spot of safflower (Carthamus tinctorius) caused by Alternaria carthami and A. alternate. Res. Pl. Dis., 9(3): 159-161.

Prasad, M. S. L., Sujatha, K. and Naresh, N., 2012, Variation in morphological and cultural characters of isolates of Alternaria carthami. J. Oilseeds Res., 29 (Spl. Issue): 362-363.

Ramegowda, G., and Naik, M. K., 2008, Morphological, cultural and physiological diversity in isolates of Alternaria spp. infecting Bt-cotton. J. Mycol. Pl. Path., 38(2): 267-271.

Singh, V., and Prasad, R. R., 2005, Integrated management of pests and diseases in safflower. Directorate of Oilseeds Research, Hyderabad, India, p. 49.

Somappa, J., Srivastava, K., Sarma, B. K., Pal, C. and Kumar, R., 2013, Studies on growth conditions of the tomato Alternaria leaf spot causing Alternaria solani. The Bioscan, 8(1): 101-104.

\section{How to cite this article:}

Madhu, M.R., M.P. Basavarajappa, I.D. Anand and Chidanand Lokapur. 2017. MorphoPhysiological Variability in Alternaria carthami Chowdhury Causing Safflower Leaf Spot. Int.J.Curr.Microbiol.App.Sci. 6(10): 3244-3250. doi: https://doi.org/10.20546/ijcmas.2017.610.380 